\title{
Benchmarking Analysis on the Performance and Emissions of Combustion Boilers within the United States for Calendar Year 2016 Jack Fuller ${ }^{1 *}$ and Yang Guo ${ }^{2}$
}

${ }^{1}$ College of Business and Economics, West Virginia University, USA

${ }^{2}$ Joseph M Katz Graduate School of Business, University of Pittsburgh, USA

\begin{abstract}
This current research effort will consider boiler conditions in 2016 within the United States. The analysis was based on data gathered from a voluntary survey completed by plant owners and operators. The survey responses included the following: (1) boiler fuel sources, (2) efficiency performance, (3) environmental performance, (4) operations and maintenance activities, and (5) boiler availability. The analysis also included future concerns with respect to daily boiler operation from the responding plant operators and management.
\end{abstract}

Keywords: Boiler; Fuels; Combustors; Boiler operations; Energy efficiency; Environmental performance

\section{Introduction}

Year 2016 witnessed the consumption of approximately 3.85 trillion kilowatt hours of electricity in the United States [1]. This ranked second in the world, with the largest electricity consumption being in China [2]. This being the case, it would seem the United States needs to pay more attention to the stability and efficiency of its power generation. This would include emissions from power generation facilities. Boilers are seen as one of the most common and traditional means to generate power (electricity and steam). Focusing on performance and emission control effectiveness should have a great impact on the country's power supply and the overall environment. Consequently, research focusing on the performance and emissions conditions of combustion boilers in the United States needs to be undertaken on a regular periodic basis.

This study was developed by conducting a voluntary survey among plant owners and operators in the United States. The survey was broken into five parts: (1) fuels and environmental effects, (2) boiler combustion efficiency performance, (3) plant operations and maintenance, (4) availability of boiler activities, and (5) concerns relating to boiler operations and maintenance. By analyzing the survey results, a better understanding of the current performance of combustion boilers in the country should assist plant owners and operators in their plants future operations and management.

\section{Fuels and Environmental Effects}

Many types of fuels are now being used for boiler combustion in order to generate power. However, statistics showed that most electricity was generated by burning fossil fuels. Natural gas was the largest energy source, contributing 34\% of electricity generation in 2016 in the United States. Coal, after natural gas, contributed $30 \%$ of electricity generation [3]. Other than fossil fuels, biomass and industrial waste were also used as fuel sources. However, the combustion of these fuels not only generate power but also emit large amounts of hazardous pollutants and greenhouse gases. For example, carbon dioxide $\left(\mathrm{CO}_{2}\right)$, carbon monoxide (CO), sulfur dioxide $\left(\mathrm{SO}_{2}\right)$, nitrogen oxides $\left(\mathrm{NO}_{\mathrm{x}}\right)$, and particulate matter (PM) [4]. To reduce the negative impacts on the environment, power plants recently have been required to take multiple actions to lower their emissions during the process of power generation. Related to boilers, the United States Environmental Protection Agency has issued the Major Source Boiler Maximum Achievable Control Technology (MACT) Rule to regulate the amount of certain types of pollutants a boiler can emit [5]. To meet the EPA's Boiler MACT standards, some emission control devices have been added to the facilities. Additionally, there were tune-up requirements in specific situations or limited-use requirements for boilers operating in certain conditions [6].

As the survey results indicated, all the responding plants used fossil fuels in their combustion boilers. The results were also consistent with those from a national study, which found that natural gas and coal were the two largest fuel sources for power generation. The primary fuel sources used in the plants included in this study were coal $(28.6 \%$ of the responding plants), gob ( $14.3 \%$ of the responding plants), natural gas $(28.6 \%$ of the responding plants), and waste coal (14.3\% of the responding plants). The remaining $14.2 \%$ of the responding plants did not indicate their fuel source. Forty-three percent of the plants in this study reported using secondary fuel sources, with $28.6 \%$ of the responding plants using coal and $14.4 \%$ using natural gas and No.2 fuel oil. The amount of three controlled emissions were analyzed as a part of this survey: (1) Actual $\mathrm{SO}_{2}$ emissions as a percent of permit (per boiler), (2) Actual $\mathrm{NO}_{\mathrm{x}}$ emission as a percent of permit (per boiler), and (3) calcium/sulfur ratios (per boiler). FBC boilers had an average of $44 \%$ of the actual amount of $\mathrm{SO}_{2}$ emission as a percent of their permit emissions and an average of $76 \%$ of the actual amount of $\mathrm{NO}_{\mathrm{x}}$ emission as a percent of permit. Stoker/Cyclone boilers had an average $26.1 \%$ of the actual amount of $\mathrm{SO}_{2}$ emission as a percent of permit and an average $85 \%$ of the actual amount of $\mathrm{NO}_{\mathrm{x}}$ emission as a percent of permit. (Due to a variety of factors, including number of Stoker and number of Cyclone boilers represented in the survey, it was decided to combine Stoker and Cyclone boiler data together.) The $\mathrm{Ca} / \mathrm{S}$ ratio was analyzed for FBC boilers, which showed a mean of 2.75. Ash disposal is also very important for emission controls. As reported, all of the fly ash and bottom ash were used for beneficial purposes in FBC boilers and $75 \%$ of both types of ash were used for beneficial purposes in Stoker/Cyclone boilers. To meet the Boiler MACT standards, one

*Corresponding author: Jack Fuller, College of Business and Economics, West Virginia University, USA, Tel: + 304-293-7935; Fax: + 304-293-7935; E-mail: Jack. Fuller@mail.wvu.edu

Received January 04, 2017; Accepted January 11, 2018; Published January 18 2018

Citation: Fuller J, Guo Y (2018) Benchmarking Analysis on the Performance and Emissions of Combustion Boilers within the United States for Calendar Year 2016 Int J Waste Resour 8: 321. doi: 10.4172/2252-5211.1000321

Copyright: (c) 2018 Fuller J, et al. This is an open-access article distributed under the terms of the Creative Commons Attribution License, which permits unrestricted use, distribution, and reproduction in any medium, provided the original author and source are credited. 
plant reported converting their largest coal-fired unit to natural gas. They also put three other boilers on "limited use".

\section{Boiler Combustion Efficiency Performance}

Boiler combustion efficiency was determined by the amount of unburned fuel and excess air in the exhaust. This refers to "fuel loss or stack loss efficiency". The extra air is the amount of the air used by the boiler beyond the amount required for complete combustion. In general, the lower the level of unburned fuels, the lower the excess air level, and the higher the efficiency rate of the burner. A $15 \%$ or less level of extra air usage would be seen as a good indication of efficiency. Different fuel sources have different efficiency rates. Normally, gas and liquid fuels, both of which have excess air levels around 15\% during the combustion process, have better efficiency performance than solid fuels [7]. However, ignoring the age factor of boilers, coal-fired boilers can reach an efficiency rate of $85 \%$. Oil-fired boilers are next in efficiency, averaging about $80 \%$ efficient and then gas-fired boilers at $75 \%$ average efficiency. Biomass-fired boilers have the lowest efficiency rate, averaging $70 \%[8]$.

The type of fuel being used in boilers is one of the most important factors influencing combustion efficiency performance. Another important factor would be the combustion technologies for which the boilers were designed. The boiler combustion efficiency performance of those boiler units in the responding plants was estimated by the technologies being used. As reported, the boilers showed an overall average efficiency rate of $82.2 \%$. Fluidized bed combustion (FBC) boilers, which were $21.7 \%$ of all reported boilers, have the highest efficiency rate, $82.5 \%$. Stoker/Cyclone boilers (34.8\% of all reported boilers) and gas-fired boilers ( $43.5 \%$ of all reported boilers) reached $79 \%$ and $79.6 \%$ efficiency rates, respectively.

\section{Plant Operations and Maintenance}

Plant operations and maintenance processes are crucial to the stability and availability of boiler activities. There are five areas needing special attention during the operations and maintenance management process. These are operations, maintenance, engineering, training, and administration [9]. The survey questions relating to this part covered four areas (all but engineering) to identify any potential problems among responding plants. As reported, $83 \%$ of the plants had energy management programs to ensure suitable operations and maintenance activities. Operator certification was only required by $67 \%$ of the plants.

A question was addressed concerning the average number of full time equivalent (FTE) personnel per gross MW capacity in different positions to identify the operations personnel structure of these responding plants (Figure 1). Operations personnel had the highest average number in FBC plants and Stoker/Cyclone plants, 0.32 and 0.21 employees per gross MW capacity, respectively. However, the average number of maintenance personnel in FBC plants (0.25) was higher than the average number of maintenance personnel in Stoker/Cyclone plants. Not surprisingly, the lowest average was for management personnel in both types of plants.

To protect the safety and efficiency of plant operations, appropriate training is very important for operators. However, only half of the plants required their operators to take training courses. For those operators willing to improve their operations skills by attending training courses, $83 \%$ of the plants would provide the opportunity in-house. Half of the remaining $17 \%$ (i.e., $8.5 \%$ ) of the plants, who did not have in-house training available, would reimburse their operators for external training.

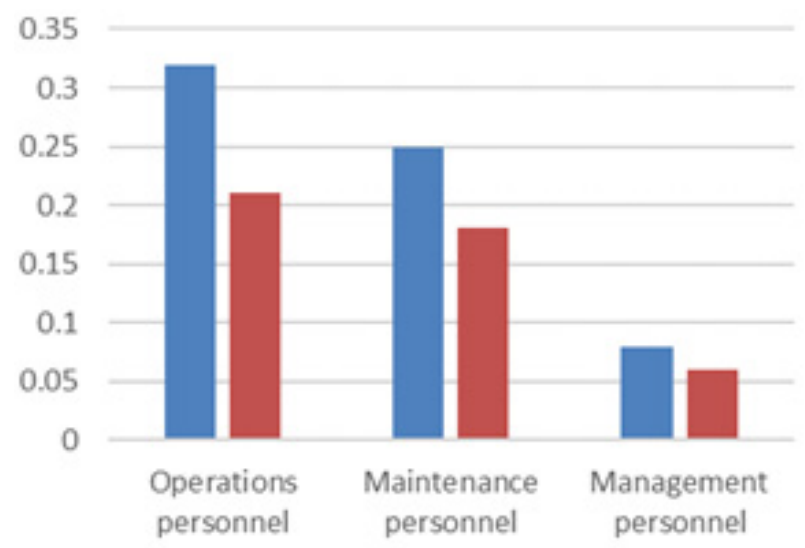

- FBC Plants Stoker/Cyclone Plants

Figure 1: Average number of FTE personnel (per gross MW capacity).

For maintenance planning, all responding plants had formal maintenance plans with different lengths and frequencies. Daily maintenance was undertaken by half of the responding plants. One third of the responding plants had monthly maintenance, and the remaining $17 \%$ did not indicate their maintenance frequency. For maintenance activities, $33 \%$ of the plants had tune-ups "as required". Sixty seven percent of the responding plants had a yearly tune-up and $20 \%$ of the plants had bi-yearly tune-ups.

\section{Availability of Boiler Activities}

Statistics showed that boilers could reach an annual availability rate ranging from a minimum of $87 \%$ to a maximum of $94 \%$ in good operating conditions. The unavailability generally came from outages [8]. There are normally two types of outages in boiler operations: (1) planned outages and (2) forced outages. All of these outages are interruptions of the boiler power generation process and influence the availability of boiler activities in different levels. The planned outages are usually for routine maintenance and inspection purposes and known in advance by plant operators. These would occur due to various reasons and would be prearranged in advance. The forced outages, while occurring infrequently, are those unpredictable interruptions not having been scheduled [10]. The reasons for forced outages could be due to a variety of reasons, such as natural disasters and operation system failures. Therefore, this kind of unavailability is quite hard to prevent. The percent of planned outages hours and forced outages hours during the unavailable hours were compared to give an assessment of the availability performance of the boilers under review.

The survey results indicated an average annual availability of $76 \%$ of all boilers in the responding plants in year 2016. Thirteen percent of all outage hours were due to forced outages. More specifically, FBC boilers had $12.5 \%$ of their outage hours forced, whereas Stoker/Cyclone boilers had $26.9 \%$ of their outage hours forced. There was insufficient outage hour information available for natural gas boilers. The percent of outage hours related to boiler technologies for both planned outages and forced outages are shown in Figure 2. FBC boiler-related forced outages hours accounted for $16.5 \%$ of all the outages hours. Stoker/Cyclone boiler related forced outages hours accounted for $40.5 \%$ of all outage hours. For planned outage hours, $78.9 \%$ of outage hours were planned for FBC boilers. This same percentage dropped to $72.9 \%$ for Stoker/Cyclone 
Citation: Fuller J, Guo Y (2018) Benchmarking Analysis on the Performance and Emissions of Combustion Boilers within the United States for Calendar Year 2016. Int J Waste Resour 8: 321. doi: 10.4172/2252-5211.1000321

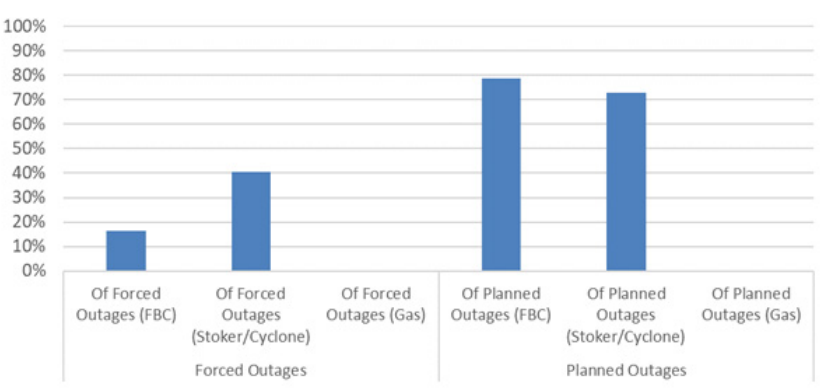

Figure 2: Percent of outage hours boiler related in 2016.

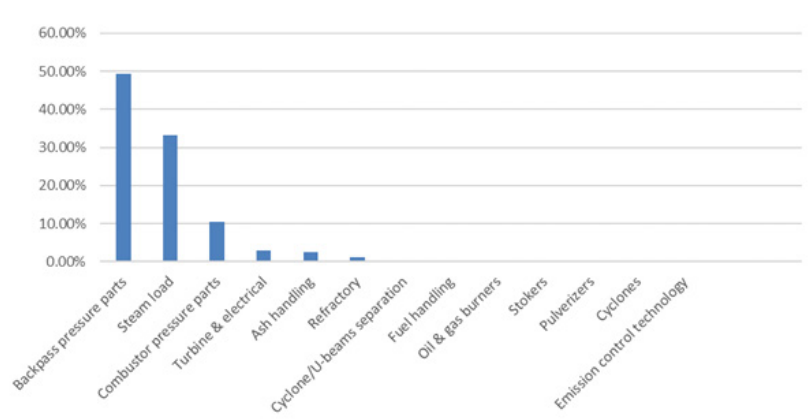

Figure 3: Forced outage causes in 2016 at FBC units (as percent of forced outage hours)

boilers. Again, there was insufficient data for natural gas boilers for this analysis. Since the forced outages were hard to prevent, the research also analyzed this issue further. Problems related to "backpass pressure parts" and "steam load" led to the majority of occurrences (82.6\%) of forced outages in FBC boilers (Figure 3). The vast majority of outage hours in Stoker/Cyclone boilers were from problems related to "combustor pressure parts" and "refractory" (Figure 4).

\section{Concerns for Future Boiler Operation and Maintenance}

Though the survey was designed as detailed as possible to identify any potential problems that might come out in the boiler operation process, a specific question with respect to concerns on future operations and maintenance was addressed to boiler operators. From the listed 33 types of concerns (Table 1), each respondent would give them a scale number from " 1 " to " 10 " for the upcoming 2017 year of operation. The degree of concern increased as the value of the scale number increases. The results, listed in Figures 5 and 6 , showed different results with respect to different types of combustion technologies. FBC plant owners and operators rated several types of concerns with fairly high scale numbers. "Turbine/electrical", "Refractory" and "Tube emission" were on average rated above "6". "Electronic controls", "Ash disposal", "Pressure parts", "Air heater", and "Loop seals" were rated on average between " 4 " and "6". With respect to Stoker/Cyclone plants, no issues listed were rated above "6". "Emission controls" and "Boiler: Combustion issues" were rated on average between " 5 " and " 6 ". "CEMs", "Fuel feeding", "Pressure parts", and "Ash handling" were rated between " 3 " and " 5 " on average.

\section{Conclusion}

The survey results suggest that most responding plants were operating successfully as to their efficiency performance and emission

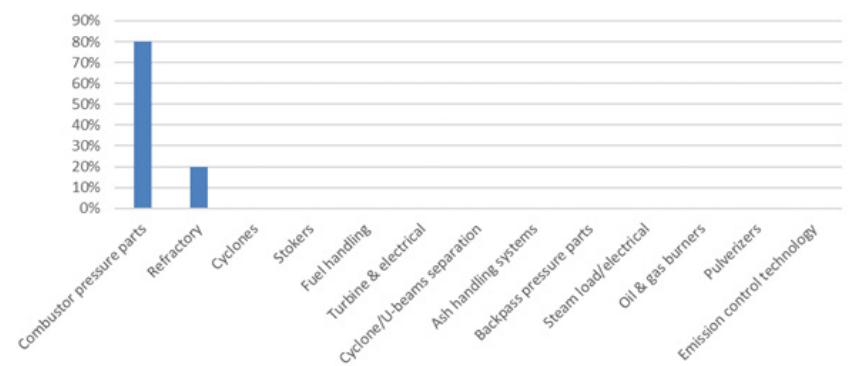

Figure 4: Forced outage causes in 2016 for stoker units (as percent of forced outage hours).

\begin{tabular}{|c|c|c|}
\hline Fuel quality & Cyclones & Ash handling \\
\hline $\begin{array}{c}\text { Fuel handling/ } \\
\text { crushing }\end{array}$ & Air heater & Bed ash \\
\hline Fuel feeding & Loop seats & Fly ash \\
\hline Pressure parts & Expansion joints & Ash regulations \\
\hline Boiler: Combustion & Electrical controls & NSR definition changes \\
\hline Boiler: Back pass & $\begin{array}{c}\text { Turbine/ } \\
\text { Electrical }\end{array}$ & Seasonal emissions \\
\hline Refractory & Tube erosion & CFBC cyclone \\
\hline Ash cooling & Combuster & Cyclones (combustion) \\
\hline Stokers & Pulverizers & Ash disposal \\
\hline Emission Controls & CEMs & Operator error \\
\hline Burners & Igniters & Other \\
\hline
\end{tabular}

Table 1: Types of concerns for future boiler operation and management.

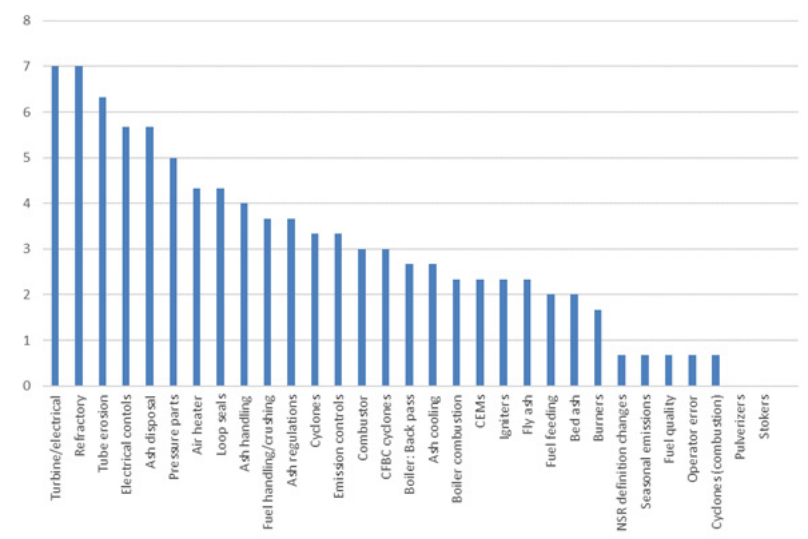

Figure 5: Year 2017 boiler O/M concern priority for FBC Plants (high=10, low=1).

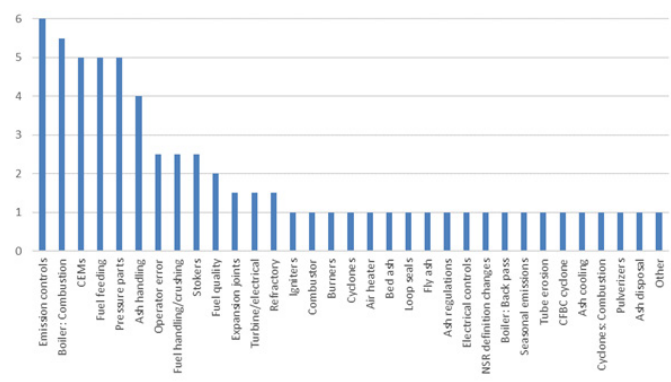

Figure 6: Year 2017 boiler O/M concern priority for stoker and cyclone plants (high=10 and low=1). 
Citation: Fuller J, Guo Y (2018) Benchmarking Analysis on the Performance and Emissions of Combustion Boilers within the United States for Calendar Year 2016. Int J Waste Resour 8: 321. doi: 10.4172/2252-5211.1000321

Page 4 of 4

control performance. However, operators still have concerns about boilers' future operations. Boilers might add required emission control equipment and submit regular assessments on certain types of pollutants to the government. However, the restricted regulations on emission controls will likely increase the cost of boiler operations. To keep the units profitable, there needs to be a way to balance the cost from the environmental improvement procedures with ongoing operations. One option to offset the economic costs of this could be in improving the power generation efficiency. Though efficiency rate is limited due to a variety of reasons, it is still possible to lower the unnecessary inefficiency during operations by training operators regularly and maintaining the facilities in a more timely and proper manner. Technology breakthroughs are crucial to realize such improvement. The United States Department of Energy has implemented a variety of projects to tackle this issue. For example, a combined heat and power (CHP) system was viewed as a more economical means for many industrial and commercial facilities to benefit themselves, as well as the environment [11]. With large scale implementation of more efficient power generation systems, companies using boilers to generate steam and electricity should be able to operate even more competitively in the future.

\section{References}

1. Statista (2017) Total electricity end use in the U.S. from 1975 to 2016 (in billion kilowatt hours).

2. Enerdata (2017) Global Energy Statistical Yearbook 2017.

3. U.S. Energy Information Administration (2017) Electricity in the U.S.

4. U.S. Energy Information Administration (2017) Electricity \& the Environment.

5. United States Environmental Protection Agency (2017) Industrial, Commercial and Institutional Boilers and Process Heaters: National Emission Standards for Hazardous Air Pollutants (NESHAP) for Major Sources.

6. http://www.nationwideboiler.com/boiler-mact-compliance/boiler-mact-guide $\mathrm{html}$

7. American Boiler Manufacturers Association (2017) Determining \& Testing Boiler Efficiency for Commercial/Institutional Packaged Boilers.

8. https://iea-etsap.org/E-TechDS/PDF/I01-ind_boilers-GS-AD-gct.pdf

9. https://energy.gov/sites/prod/files/2013/10/f3/OM_3.pdf

10. Energy Dictionary (2017) Planned outage, unplanned outage, scheduled outage.

11. Gas Technology Institute (2017) Department of Energy (DOE) CHP R\&D Projects. 